\title{
Okul Öncesi Öğretmenlerinin Öğretmenlik Mesleğine İlişkin Tutumlarının Farklı Değişkenler Açısından İncelenmesi*
}

\section{Examination of Preschool Teachers' Attitudes towards Teaching Profession in Terms of Different Variables}

\author{
İkbal Tuba ŞAHİN-SAK ${ }^{* *}$ (iD) $\quad$ Ramazan SAK $^{* *}$ \\ Nuran TUNCER ${ }^{* * * *}$
}

Received: 22 August 2018

Research Article

Accepted: 19 March 2019

\begin{abstract}
The aim of this study is to examine preschool teachers' attitudes towards teaching profession in terms of different variables. The sample of the study consisted of 417 preschool teachers. The Personal Information Form and the Attitude Scale of Teaching Profession were used to collect data. At the end of the study, it was found that the preschool teachers' attitudes toward teaching did not differ according to their genders, ages, years of teaching, number of children in their classroom and whether they participated in an activity related to their profession in last one year. However, their attitudes differed according to the sector and the institution type they worked in, the age group they taught, working status (hourly paid or salaried) and their educational level. Also, the attitude scores of preschool teachers working in private school were higher than their colleagues' working in public schools; the scores of teachers working in nursery classrooms were higher than scores of those working in kindergartens; the scores of teachers who taught six-year olds were higher than and the teachers of age four or mixed age group; the scores of hourly paid teachers were higher than salaried teachers; the scores of preschool teachers graduated from colleges (two-year) were higher than their colleagues' who graduated from school of education (four-year).
\end{abstract}

Keywords: preschool education, teaching profession, professional attitude.

ÖZ: $\mathrm{Bu}$ çalışmanın amacı, okul öncesi öğretmenlerinin mesleki tutumlarının farklı değişkenler açısından incelenmesidir. Çalışmanın örneklemini 417 okul öncesi öğretmeni oluşturmaktadır. Çalışmada veri toplamak için Kişisel Bilgi Formu ve Öğretmenlik Mesleğine Yönelik Tutum Ölçeği kullanılmıştır. Çalışmanın sonunda, çalışmaya katılan okul öncesi öğretmenlerinin öğretmenlik mesleğine ilişkin tutumlarının, cinsiyetlerine, yaşlarına, kıdemlerine, sınıflarındaki çocuk sayısına ve son bir yılda meslekleriyle ilgili bir etkinliğe katılıp katılmamalarına göre bir farklılık göstermediği belirlenmiştir. Ancak, tutumların öğretmenlerin çalıştıkları sektöre, çalıştıkları kurum türüne, eğitim verdikleri yaş grubuna, çalışma şekillerine ve öğrenim durumlarına göre farklılık gösterdiği belirlenmiştir. Ayrıca, özel okulda görev yapan öğretmenlerin mesleki tutum puanlarının devlet okullarında çalışanlarınkinden, anasınıflarında görev yapanların puanlarının bağımsız anaokullarında çalışanlarınkinden, 6 yaş grubu öğretmenlerinin puanlarının dört yaş ve karma yaş grubu öğretmenlerinkinden, ücretli öğretmenlerin puanlarının kadrolu öğretmenlerinkinden ve ön lisans mezunu öğretmenlerin puanlarının lisans mezunu öğretmenlerin puanlarından daha yüksek olduğu bulunmuştur.

Anahtar kelimeler: okul öncesi eğitim, öğretmenlik mesleği, mesleki tutum.

\footnotetext{
* This manuscript was presented at $5^{\text {th }}$ International Early Childhood Education Congress, but not completely published.

Corresponding Author: Dr., Van Yüzüncü Yıl University, Van, Turkey, ikbalsahin@gmail.com, https://orcid.org/0000-0002-9054-6212

**** Dr., Van Yüzüncü Y1l University, Van, Turkey, ramazansak06@gmail.com, https://orcid.org/0000-0002-75049429

***** Dr., Gaziosmanpaşa University, Tokat, Turkey, nurantuncer72@ gmail.com, https://orcid.org/0000-0002-87485084
}

Citation Information

Şahin-Sak, İ. T., Sak, R., \& Tuncer, N. (2019). Okul öncesi öğretmenlerinin öğretmenlik mesleğine ilişkin tutumlarının farklı değișkenler açısından incelenmesi. Kuramsal Eğitimbilim Dergisi [Journal of Theoretical Educational Science], 12(2), 819-841. 


\section{Giriş}

Tutum, kişinin bir durumu, bir varlığı olumlu veya olumsuz şekilde değerlendirerek ortaya koyduğu psikolojik eğilimdir (Eagly \& Chaiken, 1993). Bir başka ifadeyle, kişinin bir nesneye ilişkin deneyimlemiş olduğu bilişsel ve duyuşsal değerlendirmeleri bir araya getiren ve özetleyen yargılardır (Crano \& Prislin, 2006). Thurstone'a (1946; akt. Trivedi, 2011) göre ise, psikolojik bir nesneye ilişkin olumlu veya olumsuz duygunun derecesidir. Eğer kişi bir nesneye, bir duruma karşı olumlu bir duyguya sahipse, ondan hoşlandığı ya da ona karşı olumlu bir tutuma sahip olduğu, ancak aynı nesne ya da duruma karşı olumsuz bir duyguya sahipse ondan hoşlanmadığı ya da ona karşı tutumunun olumsuz olduğu söylenmektedir (Trivedi, 2011).

Tutum; duygu, düşünce ve davranıştan oluşan karmaşık bir yapıdır. Özellikle duygu ve düşünce boyutları daha içsel olsa da, davranış boyutu diğer kişiler tarafindan gözlenebilmektedir (Pickens, 2016). Kişinin kendiyle ilgili farkındalığına bağlı olarak tutumlarının etkisi yaşamının farklı alanlarında davranışlarına yansımaktadır (Fazio \& Olson, 2003). Bu alanlardan biri, kişinin mesleğidir ve mesleki tutumun önemi göz ardı edilemez. Çünkü tutumun ahlakla da ilişkili olduğu düşünüldüğünde, kişinin mesleki tutumu, üretkenliğini, istikrarını ve başarısını etkilemektedir. $\mathrm{Bu}$ da bir iş yerinin işleyişi için oldukça önemli bir durumdur (Khan, Nadeem, \& Basu, 2013).

Meslek grupları içinde özellikle öğretmenlerin tutumları ayrı bir önem taşımaktadır. Öğretmenlerin öğretme etkinliğine karşı gerçek ve potansiyel yanıtlarını belirleyen, olumlu ya da olumsuz bir biçimde farklı şekillerde tepki vermesine neden olan inanç ya da öğrenilmiş eğilimler bütünü olarak tanımlanan öğretmen tutumları, öğretmenlerin davranışlarında kendini açıkça göstermektedir (Khan, Nadeem, \& Basu, 2013). Bir başka ifadeyle, öğretmenlerin mesleki tutumları ile performansları arasında bir ilişki bulunmaktadır (Ahmad, Said, Zeb, Sihatullah, \& Ur Rehman, 2013; Ball \& Lampert, 1999). Örneğin olumlu bir mesleki tutuma sahip olan öğretmenler canla başla çalışmakta, öğrencilerine faydalı olmak ve amaçlarına ulaşmak için yüreklerini ortaya koymaktadırlar. Bu da beraberinde sevgi ve anlayışa dayalı öğretmen-öğrenci ilişkisini getirmektedir. Ayrıca öğretmenlerin olumlu mesleki tutumu yalnızca mesleğini yapmasını kolaylaştırmakla kalmamakta, onu tatmin edici hale de getirmektedir. Tersi şekilde olumsuz bir mesleki tutumla, öğrenme-öğretme süreci sıkıcı, zor ve tatsız bir hal almaktadır (Khan, Nadeem, \& Basu, 2013).

Öğretmenlerin mesleki tutumları, eğitim-öğretim sürecinin anlaşılması ve geliştirilmesi için önemlidir. Çünkü öğretmenlerin tutumları ile mesleklerini yaparken hissettikleri motivasyon ve karşılaştıkları zorluklarla baş etme yöntemleri arasında bir ilişki bulunmaktadır. Bu durum da, çocukların içinde bulunduğu öğrenme ortamını, motivasyonlarını ve başarılarını etkilemekte ve şekillendirmektedir (Organisation for Economic Co-operation and Development [OECD], 2009). Özellikle çocuklarla çalışan ve eğitim-öğretim sürecinin her aşamasında aktif olması gereken okul öncesi öğretmenlerinin mesleki tutumları kritik bir öneme sahiptir.

Dünyada doğrudan okul öncesi öğretmenlerinin mesleki tutumlarına ilişkin sınırlı sayıda çalışma bulunmaktadır. Örneğin; Jeon ve Wells (2018) tarafından yapılan çalışmada Head Start okullarında görev yapan okul öncesi öğretmenlerinin mesleki tutumları ile iş yerindeki öğretmen değişimini incelenmiş; çalışmanın sonunda, öğretmen değişimini azaltmak için, bu değişimin sebeplerinin azaltılması, öğretmenlerin 
mesleğe karşı olumlu tutumlarının ve mesleki doyumlarının artırılması gerektiği vurgulanmıştır. Vujičić ve Čamber Tambolaš (2017) tarafından okul öncesi öğretmenlerinin mesleki alg1 ve mesleğe yönelik tutumlarının incelediği çalışmada, öğretmenlerin mesleki tutumları ve mesleki gelişimleri ile gelişime yönelik modern yaklaşımlar arasında, okul öncesi öğretmenlerin sürekli öğrenmeye ve kendi uygulamalarını keşfetmeye yönelmesi anlamında bir ilişki olduğu ortaya çıkmıştır. Wells (2017) Head Start okullarında görev yapan okul öncesi öğretmenlerinin psikolojik mesleki tutumlarını incelemiş; çalışmanın sonunda, öğretmenlerin mesleki tutumlarının, kurum içi düzenlemelere, kurum içi ilişkilere ve sınıflarının yapısal kalitesine ilişkin aldıkları destek türü ve miktarından etkilendiğini belirlemiştir. Jeon, Buettner ve Hur (2016) tarafından yapılan çalışmada, Amerika'da okul öncesi öğretmenlerinin kalite profili; öğretmenlerin mesleki geçmişi, gözlemlenen süreç kalitesi ve öğretmenlik mesleğine karşı tutum gibi bazı göstergelere göre incelenmiştir. Çalışmanın sonunda, 3 profil ortaya çıkmıştır: (1) daha az deneyim, daha düşük kalite ve daha fazla olumlu mesleki tutum, (2) daha az deneyim, ortalama kalite ve daha az olumlu mesleki tutum, ve (3) daha çok deneyim, daha yüksek kalite ve karışı mesleki tutum.

Türkiye'de ise, öğretmen adaylarının mesleki tutumlarına yönelik çeşitli çalışmalar bulunmaktadır. Örneğin; Durmuşçelebi, Yıldız ve Saygı (2017) tarafından yapılan çalışmada, formasyon eğitimi alan öğretmen adaylarının öğretmenlik mesleğine ilişkin tutumlarının belirlenmesi amaçlanmıştır. Çalışmanın sonuçları; öğretmen adaylarının mesleğe değer verme boyutunda en yüksek puanı; mesleğe uyum sağlama boyutunda ise en düşük puanı aldıklarını göstermektedir. Karatekin, Merey ve Keçe (2015) sosyal bilgiler öğretmen adaylarının öğretmenlik mesleğine yönelik tutumlarını farklı değişkenler açısından incelemiş; araştırmanın sonunda, cinsiyet, öğretmenlik mesleğini seçme ve sosyal bilgiler branşını seçme değişkenine göre adayların mesleki tutumlarının anlamlı bir farklılık gösterdiğini ancak, öğrenim şekli, sınıf düzeyi, baba mesleği, ebeveynlerin eğitim durumu, ailenin gelir durumu ve yerleşim türü değişkenlerine göre tutumlarının anlamlı şekilde farklılaşmadığını belirlemişlerdir. Ekici (2014) tarafindan özel bir üniversitede pedagojik formasyon programına devam eden öğretmen adayları ile yapılan çalışmada adayların mesleki tutumları çeşitli değişkenler açısından incelenmiştir. Çalışmanın sonunda, cinsiyet, mezun olunan üniversite türü ve yaş değişkenlerine göre öğretmen adaylarının mesleki tutumlarında anlamlı bir fark bulunamamış ancak öğretmenlik mesleğini tercih nedenlerine, mezun olunan lisans programına, medeni duruma, Türkiye'de öğretmenlik mesleğinin saygın bir meslek olarak algılanıp algılanmama durumuna göre adayların tutumlarında anlamlı bir fark olduğu belirlenmiştir. Ayık ve Ataş (2014), öğretmen adaylarının mesleki tutumları ile öğretme motivasyonları arasındaki ilişkiyi belirlemek amacıyla yaptıkları çalışmada, öğretmen adaylarının mesleki tutumları ile öğretme motivasyonları arasında orta düzeyde pozitif bir ilişki olduğunu ortaya koymuşlardır. Demircioğlu ve Özdemir (2014) fen ve edebiyat fakülteleri öğrencilerinin öğretmenlik mesleğine ilişkin tutumlarını farklı değişkenler açısından inceledikleri çalışmalarında, öğrencilerin bu mesleğe yönelik tutumlarının olumlu yönde olduğunu, tutumlarının cinsiyet, sınıf düzeyi ve öğretim durumlarına göre anlamlı farklılık göstermezken bölüm değişkenine göre anlamlı bir farklılık gösterdiğini belirlemişlerdir. Engin ve Çiçekli Koç (2014), bir devlet üniversitesinin eğitim fakültesinde öğrenim gören öğretmen adaylarının öğretmenlik mesleğine yönelik tutumlarını belirlemek amacıyla yaptıkları 
çalışmalarında, adayların mesleki tutumlarının yalnızca öğrenim gördükleri lisans programlarına göre farklılaştığını ortaya koymuşlardır. Recepoğlu (2013) tarafindan yapılan çalışmada öğretmen adaylarının mesleki tutumları ile yaşam doyumları arasındaki ilişkinin incelenmesi amaçlanmış; çalışmanın sonunda, adayların mesleki tutumları ile yaşam doyumları arasında orta düzeyde pozitif bir ilişki olduğu belirlenmiştir. Aydın ve Sağlam (2012), eğitim fakültelerinin farklı bölümlerinde öğrenim gören son sınıf öğrencilerinin öğretmenlik mesleğine yönelik tutumlarını ortaya koymayı amaçladıkları çalışmalarında, öğrencilerin tutumlarının, cinsiyetlerine, bölümlerini tercih etmelerine neden olan etkene ve annelerinin eğitim düzeyine göre anlamlı olarak farklılaştığı belirlenmiştir. Tekerek ve Polat (2011) tarafından yapılan çalışmada bilişim teknolojileri ve ilköğretim matematik öğretmeni adaylarının öğretmenlik mesleğine yönelik tutumları incelenmiş; öğretmen adaylarının mesleki tutumlarında erkek öğrencilere göre kız öğrenciler lehine, annesi ortaokul mezunu olanlara göre ilkokul mezunu veya lise mezunu olanlar lehine, öğrenim gördükleri bölümü isteyerek seçmeyen öğrencilere göre isteyerek seçenler lehine anlamlı bir ilişki bulunmuştur.

Bunlara ilave olarak, Elaldı ve Yerliyurt (2016), Kızıltaş, Halmatov ve Sarıçam (2012), Karaduman (2011), Bedel (2008), Aslan ve Köksal Akyol (2006), Üstün, Erkan ve Akman (2004) tarafından yapılan çalışmalarda, okul öncesi öğretmen adaylarının öğretmenlik mesleğine ilişkin tutumları incelenmiştir. Elaldı ve Yerliyurt (2016), okulöncesi öğretmen adaylarının öz-yeterlik inançlarını ve öğretmenlik mesleğine ilişkin tutumlarını inceledikleri karma yöntem çalışmalarında, öğretmen adaylarının özyeterlik inançlarının yüksek, mesleğe karşı tutumlarının da olumlu olduğu sonucuna varmışlardır. Kızıltaş, Halmatov ve Sarıçam (2012) Ağrı'da okul öncesi öğretmenliği lisans programına devam eden öğrencilerle çalıştıkları çalışmanın sonunda, öğrencilerin cinsiyet, yaş ve aile gelir düzeylerine göre tutumları arasında anlamlı bir farklılık olduğunu belirlerken, öğretim durumunun tutum üzerinde bir etkisi olmadığını ortaya koymuşlardır. Karaduman (2011) tarafından yapılan çalışmada, okul öncesi öğretmen adaylarının mesleklerine ilişkin tutumlarında cinsiyet ve cinsiyet rolünün etkisi incelenmiş; çalışmanın sonunda, cinsiyetten ziyade cinsiyet rolünün öğretmenlerin mesleki tutumları üzerinde bir etkisi olduğu belirlenmiştir. Girgin, Özyılmaz Akamca, Ellez ve Oğuz (2010) tarafından yapılan çalışmada, okul öncesi öğretmen adaylarının öğretmenlik mesleğine yönelik tutumları, mesleki benlik saygıları ve mesleki yeterlik inançlarının çeşitli değişkenler açısından değerlendirilmesi amaçlanmıştır. Çalışmanın sonunda, adayların mesleki benlik saygısı puanı ile öğretmenlik mesleğine yönelik tutum puanları arasında pozitif ve anlamlı bir ilişki olduğu ve öğretmenlik mesleğine yönelik tutumlarının nötr olduğu bulunmuştur. Bedel (2008) ise çalışmasında, okul öncesi öğretmen adaylarının öğretmenlik mesleğine ilişkin tutumları ile birtakım kişisel özellikleri arasındaki ilişkileri incelemiş; çalışmanın sonunda, öğretmen adaylarının mesleki tutumlarının olumlu olduğunu ancak öğretmen adaylarının neredeyse yarısının ilerde bu alanla ilgili bir mesleği sürdürmeyi planlamadıklarını ortaya koymuştur. Aslan ve Köksal Akyol (2006) okul öncesi öğretmen adaylarının mesleki tutumlarını ve mesleki benlik saygılarını incelemişler; çalışmanın sonunda, adayların mesleki tutum ve mesleki benlik saygısı puanlarının devam ettikleri sınıf düzeyine göre farklılık göstermediğini ancak öğretmenliği seçme nedenlerine göre farklılık gösterdiğini belirlemişlerdir. Üstün, Erkan ve Akman (2004) ise Türkiye'de sekiz farklı üniversitede 
okul öncesi eğitim programına devam eden öğrencilerle çalışmışlar; çalışmanın sonunda, öğrencilerin bu mesleğe ilişkin tutumlarının olumlu olduğunu, kızların tutum puan ortalamalarının erkeklerin ortalamalarından daha yüksek olduğunu, okudukları üniversiteyi seçme nedenlerine göre öğretmenlik mesleğine ilişkin tutumlarının anlamlı şekilde farklılaştığını, ancak tercih sıralarına ve ortaöğretim puanlarına göre tutumlarında anlamlı bir farklılık olmadığını belirlemişlerdir. Ancak yapılan alanyazın çalışması sonucunda, okul öncesi öğretmenlerinin mesleki tutumlarının incelendiği bir çalışmaya rastlanmamıştır. $\mathrm{Bu}$ nedenle bu çalışmayla okul öncesi öğretmenlerinin mesleki tutumlarının belirlenmesi amaçlanmıştır. Böylece, okul öncesi öğretmenlerinin mesleki tutumlarının belirlenmesinin önemi göz önünde bulundurarak, alanyazındaki bir eksiğin giderilmesi amaçlanmaktadır.

\section{Yöntem}

\section{Araștırma Modeli}

"Bir konuya ya da olaya ilişkin katılımcıların görüşlerinin ya da ilgi, beceri, yetenek, tutum ve benzeri özelliklerinin belirlendiği, genellikle diğer araştırmalara göre görece daha büyük örneklemler üzerinde yapılan araştırmalara tarama araştırmaları denir" (Büyüköztürk, Kılıç Çakmak, Akgün, Karadeniz, \& Demirel, 2014, s. 177). Bu nedenle okul öncesi öğretmenlerinin mesleki tutumlarının farklı değişkenler açısından incelenmesini amaçlayan bu çalışma, tarama modelinde dizayn edilmiştir.

\section{Evren ve Örneklem}

$\mathrm{Bu}$ çalışmada, evrendeki her kişiye ulaşmak mümkün olmadığından, bu evreni en iyi yansıtacak şekilde belirlenen bir örneklem oluşturulmuş; öğretmenlerin tutumlarına yönelik veri toplanmıştır (Fraenkel \& Wallen, 2006). Çalışmanın evrenini Doğu Anadolu ve Güneydoğu Anadolu Bölgelerinde görev yapan okul öncesi öğretmenleri oluşturmaktadır. Doğu Anadolu ve Güneydoğu Anadolu Bölgelerindeki okul öncesi eğitim kurumlarından tesadüfî örnekleme yöntemiyle belirlenen öğretmenlerden 500'ü, çalışmanın örneklemi olarak belirlenmiştir. Ancak geri dönen mesleki tutum ölçeklerinden 453 tanesinden 417'si veri analizine dâhil edilmiştir. 36 ölçek eksik doldurma, aynı maddeye birden fazla cevap verme gibi nedenlerden dolayı değerlendirmeye alınmamıştır.

Çalışmanın örneklemini oluşturan okul öncesi öğretmenlerinin demografik özelliklerine ilişkin bilgilere aşağıdaki tabloda yer verilmiştir. 
Tablo 1

Çalışmanın Örneklemini Oluşturan Okul Öncesi Öğretmenlerinin Demografik Özelliklerine İlişkin Bilgiler

\begin{tabular}{|c|c|c|c|}
\hline & & $n$ & $\%$ \\
\hline \multirow{2}{*}{ Cinsiyet } & Kadın & 353 & 84.7 \\
\hline & Erkek & 64 & 15.3 \\
\hline \multirow{4}{*}{ Yaş } & $20-24$ & 88 & 21.1 \\
\hline & $25-29$ & 154 & 36.9 \\
\hline & $30-34$ & 95 & 22.8 \\
\hline & 35 ve üstü & 80 & 19.2 \\
\hline \multirow{3}{*}{ Kidem } & $1-5$ y1l & 216 & 51.8 \\
\hline & 6-10 yıl & 135 & 32.4 \\
\hline & 11 yıl ve üstü & 66 & 15.8 \\
\hline \multirow{4}{*}{ Sınıflarındaki çocuk sayısı } & $5-10$ & 51 & 12.2 \\
\hline & $11-15$ & 123 & 29.5 \\
\hline & $16-20$ & 141 & 33.8 \\
\hline & 21 ve üzeri & 102 & 24.5 \\
\hline \multirow[t]{2}{*}{ Çalışılan sektör } & Özel & 91 & 21.8 \\
\hline & Devlet & 326 & 78.2 \\
\hline \multirow[t]{2}{*}{ Kurum türü } & Bağımsız anaokulu & 233 & 55.9 \\
\hline & Anasınıfi & 184 & 44.1 \\
\hline \multirow{5}{*}{$\begin{array}{l}\text { Eğitim verilen çocukların yaş } \\
\text { grubu }\end{array}$} & 3 yaş & 45 & 10.8 \\
\hline & 4 yaş & 105 & 25.2 \\
\hline & 5 yaş & 177 & 42.4 \\
\hline & 6 yaş & 37 & 8.9 \\
\hline & Karma & 53 & 12.7 \\
\hline \multirow[t]{2}{*}{ Çalışma şekli } & Kadrolu/sözleşmeli & 328 & 78.7 \\
\hline & Ücretli & 89 & 21.3 \\
\hline \multirow[t]{3}{*}{ Öğrenim durumu } & K1z meslek lisesi & 12 & 2.9 \\
\hline & Ön lisans & 99 & 23.7 \\
\hline & Lisans & 306 & 73.4 \\
\hline \multirow{2}{*}{ Eğitim etkinliğine katılma } & Katılan & 198 & 47.5 \\
\hline & Katılmayan & 219 & 52.5 \\
\hline
\end{tabular}

Çalışmaya katılan öğretmenlerin 353'ü (\%84.7) kadın, 64’ü (\%15.3) erkektir. Yaşları, 20-24 ( $n=88, \% 21.1), 25-29(n=154, \% 36.9), 30-34(n=95, \% 22.8)$ ve 35 ve üstü $(n=80, \% 19.2)$ şeklinde değişmektedir. Öğretmenlerin yarısı $(n=216, \% 51.8) 1$ ile 5 yıl arasında kıdeme sahiptir. Bununla birlikte, 135 öğretmenin (\%32.4) kıdem süresi 
6-10 yıl arasında değişirken, 66 öğretmen (\%15.8) 11 yıl ve üstü kıdeme sahiptir. Öğretmenlerin sınıflarındaki çocuk sayısı, 5-10 ( $n=51, \% 12.2), 11-15(n=123, \% 29.5)$, 16-20 (n=141, \%33.8) ve 21 ve üzeri $(n=102, \% 24.5)$ şeklinde değişmektedir. Üç yüz yirmi altı öğretmen (\%78.2) devlet okullarında, 91 öğretmen (\%21.8) ise özel okul öncesi eğitim kurumlarında görev yapmaktadır. Öğretmenlerin 233’ü (\%55.9) bağımsız anaokullarında, 184'ü (\%44.1) ise anasınıflarında çalışmaktadır. Öğretmenlerin çalıştıkları yaş grupları, üç $(n=45, \% 10.8)$, dört $(n=105, \% 25.2)$, beş $(n=177, \% 42.4)$ ve altı $(n=37, \% 8.9)$ şeklinde değişirken, 53 öğretmen (\%12.7) çalıştıkları yaş grubunu karma olarak belirtmişlerdir. Çalışmaya katılan öğretmenlerin 328'i (\%78.7) kadrolu/sözleşmeli olarak görev yaparken, 89’u (\%21.3) ücretli öğretmendir. Öğretmenler lisans $(n=306, \% 73.4)$, ön lisans $(n=99, \% 23.7)$ ve k1z meslek lisesi $(n=12, \% 2.9)$ mezunudur. Öğretmenlerin yaklaşık yarısı $(n=198, \% 47.5)$ son bir y1l içinde meslekleri ile ilgili bir eğitim ya da etkinliğe katılırken, diğer yarısı $(n=219$, \%52.5) bu tür bir çalışmaya katılmamıştır

\section{Veri Toplama Araçları}

Çalışmada veri toplamak için Kişisel Bilgi Formu ve Öğretmenlik Mesleğine Yönelik Tutum Ölçeği (Üstüner, 2006) kullanılmıştır.

Kişisel bilgi formu. Araştırmacılar tarafından çalışmaya katılan öğretmenlerin bilgilerini öğrenmek amacıyla Kişisel Bilgi Formu hazırlanmıştır. Formda öğretmenlerin yaşlarını, cinsiyetlerini, kıdemlerini, öğrenim düzeylerini, tamamladıkları lisans programını, okulda kadrolu/sözleşmeli veya ücretli çalışma durumlarını, eğitim verdikleri yaş grubunu, bağımsız anaokulu veya anasınıfı olmak üzere çalıştıkları kurum türünü, çalıştıkları kurumun içinde bulunduğu sektörü, sınıflarındaki çocuk sayısını ve son bir yılda mesleklerine ilişkin herhangi bir eğitim ya da etkinliğe katılıp katılmadıklarını öğrenmek amacıyla 11 soru yer almaktadır.

Öğretmenlik Mesleğine Yönelik Tutum Ölçeği. Çalışmada okul öncesi öğretmenlerinin öğretmenlik mesleğine ilişkin tutumlarını belirlemek amacıyla, Üstüner (2006) tarafından geliştirilen “Öğretmenlik Mesleğine Yönelik Tutum Ölçeği” kullanılmıştır. Ölçek, tek faktörlü, 34 soruluk ve 5'li likert tipi bir ölçektir. Öğretmenlerin olumlu maddelere verdikleri "Tamamen katılıyorum" şeklindeki yanıtlara 5 puan, "Çoğunlukla katılıyorum" şeklindeki yanıtlara 4 puan, "Orta düzeyde katılıyorum" şeklindeki yanıtlara 3 puan, "Kısmen katılıyorum” şeklindeki yanıtlara 2 puan ve "Hiç Katılmıyorum" şeklindeki yanıtlara ise 1 puan verilmiştir. Olumsuz maddelerde ise bu puanlama ters şekilde gerçekleştirilmiştir. Ölçeğin iç tutarlılık katsayısı .93 olarak belirlenmiştir. Ölçekten alınan yüksek puanlar öğretmenlerin mesleklerine ilişkin tutumlarının olumlu olduğunu göstermektedir.

\section{Veri Analizi}

Toplanan veriler analize dâhil edilmeden önce cevapsız bırakılma veya birden fazla seçeneğin işaretlenme durumları açısından ölçekler incelenmiştir. Uygun doldurulmayan 36 ölçek değerlendirmeye alınmamış olup toplamda 417 ölçek analiz edilmiştir. Veri toplamada kullanılmış olan Kişisel Bilgi Formu ve Öğretmenlik Mesleğine Yönelik Tutum Ölçeğinden elde edilen verilerin SPSS 22 paket programı yardımı ile analiz ve yorumlanması yapılmıştır. 
Veri analizinde öncelikle elde edilen verilerin normal dağılım gösterip göstermediği test edilmiştir. Yapılan tüm istatiksel çalışmalarda, $\mathrm{H}_{1}$ hipotezi için değişkenler arasında anlamlı bir farklılık vardır; $\mathrm{H}_{0}$ hipotezinin kabulü için değişkenler arasında anlamlı bir farklılık yoktur şeklinde hipotezler kurulmuş olup anlamlılık düzeyi olarak 0.05 veya 0.01 kabul edilmiştir. Örneğin; $\mathrm{H}_{1}$ : Okul öncesi öğretmenlerinin mesleki tutum puanları cinsiyetlerine göre anlamlı bir farklılık göstermektedir ve $\mathrm{H}_{\mathrm{o}}$ : Okul öncesi öğretmenlerinin mesleki tutum puanları cinsiyetlerine göre anlamlı bir farklılık göstermemektedir şeklinde hipotezler test edilmiştir.

Kişisel bilgi formundan elde edilen demografik değişkenlere ilişkin frekans ve yüzdelik dağılımları gibi betimsel istatistikler hesaplanmıştır.

Araştırmada elde edilen verilerin normalliğini test etmek için KolmogorowSmirnow testi kullanılmıştır. Kolmogorow-Smirnow testinin sonucuna göre ölçekten elde edilen puanların normal dağılım gösterdiği $(n=417, p>.05)$ bulunmuştur. $\mathrm{Bu}$ nedenle verilerin analizinde iki gruptan oluşan değişkenler için bağımsız örneklemler için t-testi, ikiden fazla gruptan oluşan değişkenler için Tek Faktörlü ANOVA gibi parametrik testler kullanılmıştır.

\section{Bulgular}

Aşağıda her bir alt probleme ilişkin bulgulara yer verilmiştir.

Okul Öncesi Öğretmenlerinin Mesleki Tutum Puanları ve Cinsiyetleri Arasındaki İlişki

Tablo 2

Okul Öncesi Öğretmenlerinin Mesleki Tutum Puanlarının Cinsiyete Göre t-Testi Sonuçlart

\begin{tabular}{llllll}
\hline Cinsiyet & $N$ & $\bar{X}$ & S.s & $t$ & $p$ \\
\hline Kadın & 353 & 145.95 & 20.45 & \multirow{2}{*}{.980} & .32 \\
\cline { 1 - 4 } Erkek & 64 & 143.28 & 17.85 & & \\
\hline
\end{tabular}

Okul öncesi öğretmenlerinin mesleki tutum puanlarının cinsiyetlerine göre anlamlı olarak farklılaşıp farklılaşmadığını belirlemek için yapılan bağımsız örneklemler için $\mathrm{t}$ testi sonucunda, kadın ve erkek öğretmenlerin mesleki tutum puanları arasındaki farkın anlamlı olmadığı bulunmuştur $\left(\mathrm{t}_{417}=.980, p>.05\right)$. 
Okul Öncesi Öğretmenlerinin Mesleki Tutum Puanları ve Yaşları Arasındaki İlişki

Tablo 3

Okul Öncesi Öğretmenlerinin Mesleki Tutum Puanlarının Yaşlarına Göre Tek Faktörlü ANOVA Sonuçları

\begin{tabular}{|c|c|c|c|c|c|c|c|c|}
\hline & Yaş & $N$ & $\bar{x}$ & S.s. & $S d$ & $F$ & $p$ & Anlamlı fark \\
\hline \multirow{4}{*}{ Tutum } & $20-24$ & 88 & 145.27 & 22.82 & \multirow{4}{*}{$3 / 413$} & \multirow{4}{*}{.064} & \multirow{4}{*}{.979} & \multirow{4}{*}{--- } \\
\hline & $25-29$ & 154 & 145.22 & 18.97 & & & & \\
\hline & $30-34$ & 95 & 145.62 & 19.40 & & & & \\
\hline & 35 ve üstü & 80 & 146.37 & 20.07 & & & & \\
\hline
\end{tabular}

Okul öncesi öğretmenlerinin mesleki tutum puanlarının yaşlarına göre anlamlı olarak farklılaşıp farklılaşmadığını belirlemek için yapılan Tek Faktörlü ANOVA

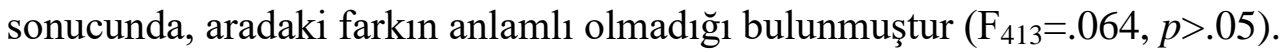

Okul Öncesi Öğretmenlerinin Mesleki Tutum Puanları ve Kıdemleri Arasındaki İlişki

Tablo 4

Okul Öncesi Öğretmenlerinin Mesleki Tutum Puanlarının Kldemlerine Tek Faktörlü ANOVA Sonuçları

\begin{tabular}{|c|c|c|c|c|c|c|c|c|}
\hline & Kıdem & $N$ & $\bar{x}$ & S.s. & $S d$ & $F$ & $p$ & Anlamlı fark \\
\hline \multirow{3}{*}{ Tutum } & $1-5$ y1l & 216 & 144.75 & 20.70 & \multirow{3}{*}{$2 / 414$} & \multirow{3}{*}{.350} & \multirow{3}{*}{.705} & \multirow{3}{*}{---} \\
\hline & $6-10$ yil & 135 & 146.43 & 18.64 & & & & \\
\hline & 11 yıl ve üstü & 66 & 146.31 & 20.99 & & & & \\
\hline
\end{tabular}

Okul öncesi öğretmenlerinin mesleki tutum puanlarının kıdemlerine göre anlamlı olarak farklılaşıp farklılaşmadığını belirlemek için yapılan Tek Faktörlü ANOVA sonucunda, aradaki farkın anlamlı olmadığı bulunmuştur $\left(\mathrm{F}_{414}=.350, p>.05\right)$. 


\section{Okul Öncesi Öğretmenlerinin Mesleki Tutum Puanları ve Sınıflarındaki Çocuk Sayısı Arasındaki İlişki}

Tablo 5

Okul Öncesi Öğretmenlerinin Mesleki Tutum Puanlarının Sınıflarındaki Çocuk Sayısına Göre Tek Faktörlü ANOVA Sonuçları

\begin{tabular}{|c|c|c|c|c|c|c|c|c|}
\hline & Çocuk sayısı & $N$ & $\bar{x}$ & S.s. & $S d$ & $F$ & $p$ & Anlamlı fark \\
\hline \multirow{4}{*}{ Tutum } & $5-10$ & 51 & 148.58 & 18.86 & \multirow{4}{*}{$3 / 413$} & \multirow{4}{*}{.555} & \multirow{4}{*}{.645} & \multirow{4}{*}{---} \\
\hline & $11-15$ & 123 & 144.43 & 20.02 & & & & \\
\hline & $16-20$ & 141 & 145.84 & 21.25 & & & & \\
\hline & 21 ve üzeri & 102 & 144.95 & 19.15 & & & & \\
\hline
\end{tabular}

Okul öncesi öğretmenlerinin mesleki tutum puanlarının sınıflarındaki çocuk sayısına göre anlamlı olarak farklılaşıp farklılaşmadığını belirlemek için yapılan Tek Faktörlü ANOVA sonucunda, aradaki farkın anlamlı olmadığ bulunmuştur $\left(\mathrm{F}_{413}=.555\right.$, $p>.05)$.

\section{Okul Öncesi Öğretmenlerinin Mesleki Tutum Puanları ve Çalıştıkları Sektör Arasındaki İliş̧i}

Tablo 6

Okul Öncesi Öğretmenlerinin Mesleki Tutum Puanlarının Çalıştıkları Sektör Değişkenine Göre t Testi Sonuçları

\begin{tabular}{lccccc}
\hline Çalışlan sektör & $N$ & $\bar{x}$ & $S . s$ & $t$ & $p$ \\
\hline Özel & 91 & 151.95 & 12.78 & \multirow{2}{*}{3.491} & \multirow{2}{*}{.001} \\
\cline { 1 - 4 } Devlet & 326 & 143.75 & 21.35 & & \\
\hline
\end{tabular}

Okul öncesi öğretmenlerinin mesleki tutum puanlarının çalıştıkları sektöre göre anlamlı olarak farklılaşıp farklılaşmadığını belirlemek için yapılan bağımsız örneklemler için $\mathrm{t}$ testi sonucunda, özel sektörde ve devlet okullarında görev yapan öğretmenlerin mesleki tutum puanları arasındaki farkın anlamlı olduğu bulunmuştur $\left(\mathrm{t}_{417}=3.491, p<.05\right)$. Tablo 6 incelendiğinde, özel sektörde çalışan okul öncesi öğretmenlerinin ortalamalarının $(\bar{x}=151.95)$, devlet okullarında çalışan okul öncesi öğretmenlerinin ortalamalarından $(\bar{x}=143.7)$ yüksek olduğu görülmektedir. 
Okul Öncesi Öğretmenlerinin Mesleki Tutum Puanları ve Çalıştıkları Kurum Türü Arasındaki İlişki

Tablo 7

Okul Öncesi Öğretmenlerinin Mesleki Tutum Puanlarının Çalıştıkları Kurum Türüne Göre t Testi Sonuçlart

\begin{tabular}{lccccc}
\hline Kurum türü & $N$ & $\bar{x}$ & S.s & $t$ & $p$ \\
\cline { 1 - 5 } Bă̆ımsız anaokulu & 233 & 143.18 & 22.09 & & \\
\cline { 1 - 2 } Anasınıfı & 184 & 148.53 & 16.77 & & .007
\end{tabular}

Okul öncesi öğretmenlerinin mesleki tutum puanlarının çalıştıkları kurum türüne göre anlamlı olarak farklılaşıp farklılaşmadığını belirlemek için yapılan bağımsız örneklemler için t testi sonucunda, bağımsız anaokullarında ve ilkokullar bünyesindeki anasınıflarında görev yapan öğretmenlerin mesleki tutum puanları arasındaki farkın anlamlı olduğu bulunmuştur $\left(\mathrm{t}_{417}=-2.727, p<.05\right)$. Tablo 7 incelendiğinde, anasınıflarında çalışan okul öncesi öğretmenlerinin ortalamalarının ( $\bar{x}=148.53)$, bağımsız anaokullarında görev yapan meslektaşlarının ortalamalarından yüksek olduğu görülmektedir $(\bar{x}=143.18)$.

Okul Öncesi Öğretmenlerinin Mesleki Tutum Puanları ve Eğitim Verilen Çocukların Yaş Grupları Arasındaki İlişki

Tablo 8

Okul Öncesi Öğretmenlerinin Mesleki Tutum Puanlarının Ĕgitim Verilen Çocukların Yaş Grubuna Göre Tek Faktörlü ANOVA Sonuçları

\begin{tabular}{|c|c|c|c|c|c|c|c|c|}
\hline & $\begin{array}{l}\text { Çocukların } \\
\text { yaş grubu }\end{array}$ & $N$ & $\bar{x}$ & S.s. & $S d$ & $F$ & $p$ & Anlamlı fark \\
\hline \multirow{5}{*}{ Tutum } & 3 yaş & 45 & 145.95 & 17.89 & \multirow{5}{*}{$4 / 412$} & \multirow{5}{*}{2.853} & \multirow{5}{*}{.024} & \multirow{5}{*}{$\begin{array}{l}\text { D-B } \\
\text { D-E }\end{array}$} \\
\hline & 4 yaş & 105 & 143.39 & 20.69 & & & & \\
\hline & 5 yaş & 177 & 145.53 & 20.72 & & & & \\
\hline & 6 yaş & 37 & 155.37 & 14.44 & & & & \\
\hline & Karma & 53 & 142.64 & 20.29 & & & & \\
\hline $\mathrm{A}=3$ Yaş & $\mathrm{B}=4$ Yaş & & 5 Yaş & $\mathrm{D}=$ & Yaş & $\mathrm{E}=$ & $\mathrm{ma}$ & \\
\hline
\end{tabular}

Okul öncesi öğretmenlerinin mesleki tutum puanlarının eğitim verilen çocukların yaş grubuna göre anlamlı olarak farklılaşıp farklılaşmadığını belirlemek için yapılan Tek Faktörlü ANOVA sonucunda, aradaki farkın anlamlı olduğu bulunmuştur $\left(\mathrm{F}_{412}=2.853, p<.05\right)$. Farkın hangi gruplar arasında olduğunu belirlemek için çoklu karşılaştırma testlerinden "Tukey" testi kullanılmış; altı yaş grubu öğretmenlerinin mesleki tutum ortalamalarının ( $\bar{x}=155.37)$, dört yaş $(\bar{x}=143.39)$ ve karma yaş grubuna $(\bar{X}=142.64)$ eğitim veren öğretmenlerin ortalamalarından yüksek olduğu belirlenmiştir. 


\section{Okul Öncesi Öğretmenlerinin Mesleki Tutum Puanları ve Çalışma Şekilleri Arasındaki İlişki}

Tablo 9

Okul Öncesi Öğretmenlerinin Mesleki Tutum Puanlarının Çalışma Şekillerine Göre $t$ Testi Sonuçları

\begin{tabular}{lccccc}
\hline Çalışma şekli & $N$ & $\bar{X}$ & S.s & $t$ & $p$ \\
\hline Kadrolu/sözleşmeli & 328 & 144.41 & 21.27 & & .027 \\
\hline Ücretli & 89 & 149.71 & 14.17 & & -2.222 \\
\hline
\end{tabular}

Okul öncesi öğretmenlerinin mesleki tutum puanlarının çalışma şekillerine göre anlamlı olarak farklılaşıp farklılaşmadığını belirlemek için yapılan bağımsız örneklemler için t testi sonucunda, kadrolu/sözleşmeli olarak çalışan öğretmenlerle ücretli olarak görev yapan öğretmenlerin puanları arasındaki farkın anlamlı olduğu bulunmuştur $\left(\mathrm{t}_{417}=-2.222, p<.05\right)$. Tablo 9 incelendiğinde, ücretli olarak çalışan öğretmenlerin ortalamalarının ( $\bar{x}=149.71)$, kadrolu/sözleşmeli çalışan okul öncesi öğretmenlerinin ortalamalarından ( $\bar{x}=144.41)$ yüksek olduğu görülmektedir.

\section{Okul Öncesi Öğretmenlerinin Mesleki Tutum Puanları ve Öğrenim Durumları Arasındaki İlişki}

Tablo 10

Okul Öncesi Öğretmenlerinin Mesleki Tutum Puanlarının Öğrenim Durumlarına Göre t Testi Sonuçları

\begin{tabular}{lccccc}
\hline Öğrenim duгитu & $N$ & $\bar{x}$ & $S . s$ & $t$ & $p$ \\
\hline Ön lisans & 99 & 152.97 & 12.98 & & \\
\hline Lisans & 306 & 143.29 & 21.41 & & .253 \\
\hline
\end{tabular}

Okul öncesi öğretmenlerinin mesleki tutum puanlarının öğrenim durumlarına göre anlamlı olarak farklılaşıp farklılaşmadığını belirlemek için yapılan bağımsız örneklemler için $\mathrm{t}$ testi sonucunda, ön lisans ve lisans mezunu okul öncesi öğretmenlerinin puanları arasındaki farkın anlamlı olduğu bulunmuştur $\left(\mathrm{t}_{405}=4.253\right.$, $p<.05)$. Tablo 10 incelendiğinde, ön lisans mezunu okul öncesi öğretmenlerinin ortalamalarının ( $\bar{x}=152.97)$, lisans mezunu öğretmenlerin ortalamalarından $(\bar{x}=143.29)$ yüksek olduğu görülmektedir. 
Okul Öncesi Öğretmenlerinin Mesleki Tutum Puanları ve Eğitim Etkinliklerine Katılma Durumları Arasındaki İlişki

Tablo 11

Okul Öncesi Öğretmenlerinin Mesleki Tutum Puanları Ĕ̆itim Etkinliklerine Katılma Durumlarına Göre t Testi Sonuçları

\begin{tabular}{lccccc}
\hline Katılma durumu & $N$ & $\bar{x}$ & S.s & $t$ & $p$ \\
\hline Katılan & 198 & 146.79 & 18.07 & \multirow{2}{*}{1.213} & \multirow{2}{*}{.226} \\
\hline Katılmayan & 219 & 144.41 & 21.71 & & \\
\hline
\end{tabular}

Okul öncesi öğretmenlerinin mesleki tutum puanlarının eğitim etkinliklerine katılma durumlarına göre anlamlı olarak farklılaşıp farklılaşmadığını belirlemek için yapılan bağımsız örneklemler için t testi sonucunda, son bir yılda meslekleriyle ilgili bir etkinliğe katılan ve katılmayan öğretmenlerin mesleki tutum puanları arasındaki farkın anlamlı olmadığı bulunmuştur $\left(\mathrm{t}_{417}=1.213, p>.05\right)$

\section{Tartışma ve Sonuç}

Çalışmanın sonuçları, okul öncesi öğretmenlerinin mesleki tutumlarının cinsiyetlerine, yaşlarına, kıdemlerine, sınıflarındaki çocuk sayısına ve son bir yılda meslekleriyle ilgili bir etkinliğe katılıp katılmama durumlarına göre değişmediğini göstermektedir. İlgili alanyazında, öğretmenlik mesleğine ilişkin tutumun cinsiyete göre değişip değişmediğine ilişkin farklı sonuçları olan çalışmalar bulunmaktadır. Örneğin; Yaşar Ekici (2015), Bhargava ve Pathy (2014), Engin ve Çiçekli Koç (2014), Bulut (2009) ve Tanel, Kaya Şengören ve Tanel (2007) tarafindan öğretmen adaylarıyla, Divya (2014) ve Kalhotra (2014) tarafindan ise öğretmenlerle yapılan çalışmalar da bu çalışmanın da sonuçlarını doğrular şekilde, cinsiyet değişkenine göre öğretmenlik mesleğine ilişkin tutumların değişmediği belirlenmiştir. Bununla birlikte, Karaduman (2011) ve Üstün, Erkan ve Akman'ın (2004) okul öncesi öğretmen adaylarının, Alkan (2018), Musa ve Bichi (2015), Karatekin, Merey ve Keçe (2015) ve Tekerek ve Polat'ın (2011) ise farklı bölümlerde öğrenim gören adayların mesleki tutumlarını belirlemek amacıyla yaptıkları çalışmalarda, kız öğrencilerin mesleki tutum puanlarının erkek öğrencilerinkinden yüksek olduğu belirlenmiştir. Özellikle kız öğrencilerin mesleki tutum puanlarının yüksek çıkması, öğretmenliğin kadın mesleği olarak algılanması ile açıklanmıştır (Karaduman, 2011; Üstün, Erkan, \& Akman, 2004). Ancak bu çalışmada cinsiyete göre mesleki tutumun değişmemesi hem erkek hem de kadın öğretmenlerin mesleklerini aynı oranda benimsedikleri ve önemsedikleri şeklinde açıklanabilir (Tanel, Kaya Şengören, \& Tanel, 2007). Çünkü son yıllarda özellikle okul öncesi eğitim alanında erkek öğretmenlerin sayısının artış görmesiyle birlikte (Sak, Şahin-Sak, \& Yerlikaya, 2015), erkek öğretmenlerin bu alanda olması, gerek veliler gerekse meslektaşları tarafından daha az yadırganır hale gelmiştir. $\mathrm{Bu}$ da, erkek öğretmenlerin de kadın öğretmenler kadar mesleklerini benimsemiş olmalarını ve mesleklerine karşı tutumlarının olumlu olmasını sağlamış olabilir.

Çalışmanın bir başka sonucu olarak, yaşa ve kıdemlerine göre okul öncesi öğretmenlerinin mesleki tutumlarının farklılaşmadığı belirlenmiştir. Alkan (2018) ve 
Yaşar Ekici (2015) öğretmen adayları, Soibamcha (2016) ise öğretmenlerle yapmış oldukları çalışmalarda, yaşa ilişkin bulguyu destekler nitelikte sonuçlara ulaşmışlardır. Kalhotra ise (2014) başarılı ve başarısız öğretmenlerin öğretmenlik mesleğine ilişkin tutumlarını incelemiş; bu çalışmanın sonuçlarına paralel olarak yaş ve deneyimin öğretmenlerin tutumları üzerinde etkili olmadığını belirlemiştir. Yaş ve deneyim birlikte arttığından, öğretmenlerin mesleki tutumlarının yaş ve kıdeme göre farklılaşmamış olması birbiriyle tutarlı bir bulgudur.

Bir başka sonuca göre, öğretmenlerin mesleki tutumları sınıflarındaki çocuk sayısına göre bir farkl1lık göstermemektedir. NAEYC [National Association for the Education of Young Children] (2017) okul öncesi eğitim sınıflarındaki ortalama ideal yetişkin-çocuk oranını 1:10 olarak ifade etmiştir. Ancak bu, Türkiye'de çok farkında olunan bir durum değildir ve bir okul öncesi öğretmeninin sınıfında genellikle 16-18 arasında çocuk bulunmaktadır. Hatta bazı durumlarda bu sayı 25-26'yı bulmaktadır. Bir başka ifadeyle, Türkiye'de okul öncesi eğitim sınıflarındaki çocuk sayısı ideal olandan oldukça uzak ancak genellikle birbirine yakın olduğu için, bu durumun öğretmenlerin mesleki tutumlarında bir farklılık yaratmadığı düşünülmektedir. Ancak okul öncesi öğretmenleri ile yapılan farklı çalışmalarda, okul öncesi sınıflarında mevcudun düşük olmasının gerek öğretmen gerekse çocuk için her zaman avantaj olduğu vurgulanmaktadır (Jambunathan \& Caulfield, 2008; Özkubat, 2013; Sak, TantekinErden, \& Morrison, 2016)

Ayrıca, öğretmenlerin mesleki tutumları, son bir yılda meslekleriyle ilgili bir etkinliğe katılıp katılmama durumlarına göre farklılaşmamaktadır. Öğretmenlerin mesleklerine tutumları, sahip olunan diğer tutumlar gibi tecrübelerle gelişmekte ve değişmektedir (Kağıtçıbaşı, 1985; Semerci \& Semerci, 2004). Bir başka ifadeyle, bu zamana yayılan bir süreçtir. Bir yıl gibi kısa bir sürede okul öncesi öğretmenlerinin katılacakları mesleki etkinlikler sınırlı olacağından, öğretmenlerin mesleki tutumları üzerindeki bir etkisi olmadığı düşünülmektedir.

Çalışmada ayrıca, özel okulda görev yapan öğretmenlerin mesleki tutumları ile devlet okullarında görev yapanların tutumları arasında özel okulda çalışanlar lehine bir sonuç ortaya çıkmıştır. Bu durumun özel okullar ve devlet okulları arasındaki birtakım farklılıklardan kaynaklandığı düşünülmektedir. Örneğin, devlet okullarında öğretmenler okulların fiziksel özellikleri ile ilgili birtakım sıkıntılar yaşarken, yapmak istedikleri etkinliklerinden bazılarını uygulamaya koyamamaktadırlar. Ancak özel okullar bu anlamda öğretmenlere daha fazla firsat sunmakta, öğretmenleri zengin materyaller ve fiziksel düzenlemelerle desteklemektedirler. Şahin-Sak, Tantekin-Erden ve PollardDurodola (2018) tarafından yapılan bir çalışmada özel okulda görev yapan öğretmenlerin inanç ve uygulamaları arasında, devlet okullarında görev yapan meslektaşlarınınkilere göre daha fazla tutarlılık olduğu ortaya koyulmuş; bunun sebebi olarak da devlet okullarındaki birtakım fiziksel yetersizliklerden dolayı öğretmenlerin yapmak istediklerini uygulamaya koyamamaları gösterilmiştir. Bir başka çalışmada ise, yine devlet okullarında görev yapan öğretmenler özel okullarına göre sınıflardaki çocuk sayısının çok fazla olduğuna vurgu yapıp bunun da sınıf yönetiminde ve çocuklarla birebir yapılan uygulamalarda sıkıntılara neden olduğuna dikkat çekerken, özel okullarda profesyonel yardım ve rehberlik desteğinin daha kolay alınması ve teknolojinin daha etkili şekilde kullanılmasına da vurgu yapmışlardır (İlgar, 2014). 
Bütün bu imkan ve deneyimler, özellikle özel okullarda görev yapan öğretmenlerin mesleklerine karşı tutumlarını olumlu etkiliyor olabilir.

Anasınıflarında çalışan öğretmenlerin mesleki tutumları ile bağımsız anaokullarında görev yapan öğretmenlerin mesleki tutumları arasında anasınıflarında çalışanlar lehine bir sonuç ortaya çıkmıştır. Bu durumun, öğretmenlerin çalışma saatlerinden kaynaklanıyor olabileceği düşünülmektedir. Bağımsız anaokullarında öğretmenler tam gün çalışırken anasınıflarında genellikle ikili eğitim söz konusudur ve öğretmenler yarım gün çalışmaktadırlar. $\mathrm{Bu}$ da öğretmenin günün geri kalanında kendine zaman ayırabilmesi, bir sonraki gün yapacağı eğitim etkinliklerini planlaması ve bu etkinlikler için gerekli materyalleri hazırlaması anlamına gelmektedir ki; bu durum öğretmenin mesleki tutumunu olumlu şekilde etkileyebilmektedir. Örneğin; Bakay (2014) tarafından yapılan bir çalışmada, tam gün eğitim yapılan okullardaki öğretmenlerin devamsızlıklarının ikili eğitim yapılan okullarda çalışan öğretmenlerin devamsızlıklarından daha fazla olduğu ortaya koyulmuş ve ikili eğitim yapan okullardaki öğretmenlerin ders bitiminde işlerini halledebilmelerinden dolayı daha az devamsızlık ihtiyacı duydukları ifade edilmiştir. Bununla birlikte, özellikle kadın öğretmenlerin ev ve çocuklarına zaman ayırabilmek amacıyla ikili öğretimi tercih ettikleri düşünülmektedir (Aybek, 2017). Bu çalışmada da, okul öncesi öğretmenliğinin kadın egemen bir meslek grubu olmasının bu sonuca neden olabileceği düşünülmektedir.

Öğretmenlerin mesleki tutumları eğitim verdikleri yaş grubuna göre farklılık gösterirken, 6 yaş grubu öğretmenlerinin puanlarının dört yaş ve karma yaş grubu öğretmenlerinkinden daha yüksek olduğu belirlenmiştir. Okul öncesi eğitim döneminde altı yaş grupları, pek çok beceriyi kazanmış, ilkokula hazır olan yaş grubudur. Bu nedenle öğretmenler, altı yaş grubunda sınıf yönetimi, etkinlik seçimi gibi konularda daha rahat olabilmektedir. Örneğin; Şahin-Sak (2015) okul öncesi öğretmen adaylarının sınıf yönetimi ile ilgili öz-yeterlik inançlarını belirlemeyi amaçladığı çalışmasında, öğretmen adaylarının büyük yaş grupları ile çalışmaları durumunda sınıf yönetiminde sorun yaşamayacaklarını düşündüklerini ancak küçük yaş grupları ile çalışırken kendilerini daha az yeterli gördüklerini ortaya koymuştur. Bununla birlikte, Sak, ŞahinSak, Şahin ve Şahin (2018) tarafından yapılan bir başka çalışmada ise, okul öncesi öğretmen adaylarının anasınıflarında karma yaş gruplarına ilişkin görüşleri incelenmiş ve öğretmen adaylarının sınıf hâkimiyetini sağlama ve uygun etkinlikler planlama gibi konularda zorluklar yaşayacaklarını düşündüklerinden karma yaş gruplarıyla çalışma konusunda tereddütleri olduğu belirlenmiştir. Bu çalışmanın bulgusunun da, her iki çalışmanın bulgusuyla paralel olduğu düşünülmektedir.

Ücretli öğretmenler ile kadrolu öğretmenlerin mesleki tutumları arasında ücretli öğretmenler lehine bir sonuç ortaya çıkmıştır. Alanyazında genellikle ücretli öğretmenlerin yaşadıkları olumsuzluklara vurgu yapılmış; ücretli öğretmenlerin mesleğe olan bağlılıklarının, performanslarının, mesleki açıdan yeterliklerinin ve sorumluluk alma durumlarının düşük olduğu (Doğan, Demir, \& Turan, 2013; Öğülmüş, Yıldırım, \& Aslan, 2013), tükenmişlik yaşadıkları (Çınkır \& Kurum, 2017) ve kadrolu meslektaşlarına göre mesleki doyumlarının düşük olduğu (Yayla, Sak, Şahin-Sak, \& Taşkın, 2018) belirlenmiştir. Ancak bu çalışmanın sonunda bu sonuçlardan farklı olarak ücretli öğretmenlerin mesleki tutumlarının kadrolu öğretmenlerden daha olumlu olduğu ortaya çıkmıştır. Bu durum, ücretli öğretmenlerin genellikle yeni mezun olmuş, atanma 
dönemini bekleyen veya Kamu Personeli Seçme Sınavına (KPSS) girmek için hazırlanan; bir başka ifadeyle, mesleğe yeni atılacak idealist öğretmenler olmasının bir sonucu olabilir.

Öğretmenlerin mesleki tutumları öğrenim durumlarına göre farklılık gösterirken, ön lisans mezunu öğretmenlerin puanlarının lisans mezunu öğretmenlerin puanlarından daha yüksek olduğu ortaya çıkmıştır. Bu bulgunun, ön lisans mezunu okul öncesi öğretmenlerinin genellikle kız meslek lisesi mezunu olmalarının bir sonucu olabileceği düşünülmektedir. Çünkü kız meslek liseleri, gerek etkinlikler gerekse uygulama süreci açısından öğrencilere önemli fırsatlar sunmakta; öğrencileri öğretmenlik mesleğine hazırlamaktadır. Bu durum iki yıllık ön lisans eğitimi ve öğretmenlikle birlikte gelen sınıf içi deneyimle birleşince, okul öncesi öğretmenlerinin mesleki tutumlarını olumlu etkilemiş olabilir.

Sonuç olarak, çalışmaya katılan okul öncesi öğretmenlerinin öğretmenlik mesleğine ilişkin tutumları, cinsiyetlerine, yaşlarına, kıdemlerine, sınıflarındaki çocuk sayısına ve son bir yılda meslekleriyle ilgili bir etkinliğe katılıp katılmamalarına göre bir farklılık göstermemektedir. Ancak, tutumların öğretmenlerin çalıştıkları sektöre, çalıştıkları kurum türüne, eğitim verdikleri yaş grubuna, çalışma şekillerine ve öğrenim durumlarına göre farklılık gösterdiği belirlenmiştir. Ayrıca, özel okulda görev yapan öğretmenlerin mesleki tutum puanlarının devlet okullarında çalışanlarınkinden, anasınıflarında görev yapanların puanlarının bağımsız anaokullarında çalışanlarınkinden, 6 yaş grubu öğretmenlerinin puanlarının dört yaş ve karma yaş grubu öğretmenlerinkinden, ücretli öğretmenlerin puanlarının kadrolu öğretmenlerinkinden ve ön lisans mezunu öğretmenlerin puanlarının lisans mezunu öğretmenlerin puanlarından daha yüksek olduğu bulunmuştur.

\section{Öneriler}

Çalışmanın bulguları 1şığında, okul öncesi öğretmenlerinin mesleki tutumlarını etkileyecek faktörlerin farklı çalışmalarla ortaya koyulması ve bu faktörlere bağlı olarak öğretmenlerin tutumlarını olumlu yönde etkileyecek iyileştirmelerin yapılması önerilmektedir. Öğretmenlerin mesleki tutumlarının, mesleki doyumlarını, mesleki tükenmişliklerini ve işe devam etme durumlarını yakından etkilediği göz önünde bulundurularak, öğretmenlerin yalnızca profesyonel anlamda değil, sosyal ve ekonomik anlamda da desteklenmesine ilişkin çeşitli çalışmalar yapılmalıdır. Özel okulda görev yapan öğretmenlerin mesleki tutumlarının daha olumlu olduğu göz önünde bulundurularak, özellikle devlet okullarındaki öğretmenlerin çalışma ortamları iyileştirilmeli ve öğretmenlere zamana yayılan ve aktif katılım sağlayabilecekleri mesleki gelişim etkinlikleri sunulmalıdır. Öğretmenlerin çalışma saatleri ve izin durumları, öğretmenlerin çalışma motivasyonunu ve iş verimini artıracak şekilde, öğretmenlerin ihtiyaçları göz önünde bulundurularak düzenlenmelidir. Okul öncesi öğretmenlerinin özellikle lisans eğitimleri süresince farklı yaş grubundan çocuklarla deneyimler yaşamaları, hem bu konudaki endişelerini giderecek hem de bu konuyu öğretmen olduklarında- onlar için büyük bir sorun olmaktan çıkaracaktır. Bu nedenle, okul deneyimi ve öğretmenlik uygulamaları derslerinde, öğretmen adaylarının 36-66 aylık çocukların tamamıyla zaman geçirmeleri ve etkinlik yapmaları sağlanmalıdır. Devlet okullarında kadrolu olarak görev yapan öğretmenlerin meslekleri ile ilgili uygulamalarının zaman içerisinde tekdüze hale gelmesi buna bağlı olarak da mesleki 
tutumlarının olumsuz etkilenmesi beklenen bir durumdur. Bu nedenle ücretli-kadrolu öğretmen ayrımı olmadan bütün öğretmenlere, eğitim sürecine aktif şekilde katılma imkanı verilmeli; özellikle okul öncesi eğitim süreciyle ilgili düzenlemelerde fikirlerini, ihtiyaçlarını paylaşmaları sağlanmalı, yaratıcılıkları ve farklı fikirleri desteklenmelidir.

Bundan sonra yapılacak çalışmalarda, okul öncesi öğretmenlerinin mesleki tutumlarının karma yöntem araştırmasıyla incelenmesi, ortaya çıkan bazı sonuçların nedenlerinin de belirlenmesi açısından önemli olacaktır. Okul öncesi öğretmenlerinin mesleki tutumları ile sınıf içi uygulamaları veya sınıflarındaki çocukların çeşitli becerileri arasındaki ilişkiler incelenebilir. Okul öncesi öğretmen adaylarının mesleki tutumlarının zaman içerisinde nasıl değişim gösterdiği boylamsal çalışmalarla incelenebilir. Okul öncesi öğretmenlerinin ve öğretmen adaylarının mesleklerine ilişkin tutumları karşılaştırılabilir. 


\section{Summary}

Purpose and Significance: The professional attitudes of teachers are important for understanding and developing the educational process because there is a relationship between the attitudes of teachers and the motivation which they have while doing their profession or the strategies which they use to deal with the problems that they encounter. This influences and forms the learning environment, motivation, and success of children. Professional attitudes of especially preschool teachers who work with young children and should be active during the educational process have a critical role. Therefore, the aim of this study is to examine preschool teachers' attitudes towards teaching profession in terms of different variables.

Method: This study is designed as a survey research -a quantitative method. Since it was not possible to reach every person in population, a sample which reflected the population was selected. The sample consisted of 417 preschool teachers. The Personal Information Form and the Attitude Scale of Teaching Profession were used to collect data. Descriptive statistics, t-tests and one-way ANOVA were used for data analysis.

Results: At the end of the study, it was found that the preschool teachers' attitudes toward teaching did not differ according to their genders, ages, years of teaching, number of children in their classroom and whether they participated in an activity related to their profession in last one year. However, their attitudes differed according to the sector and the institution type they worked in, the age group they taught and their educational level. Also, the attitude scores of preschool teachers working in private school were higher than their colleagues' working in public schools; the scores of teachers working in nursery classrooms were higher than scores of those working in kindergartens; the scores of teachers who taught six-year olds six were higher than and the teachers of age four or mixed age group; the scores of hourly paid teachers were higher than salaried teachers; the scores of preschool teachers graduated from colleges (two-year) were higher than their colleagues' who graduated from school of education (four-year).

Discussion and Conclusions: The attitude scores of preschool teachers working in private school were higher than their colleagues' working in public schools. It is thought that this result is related to some differences in public and private schools in Turkey. For instance, there are some deficiencies related to environment of public schools so teachers working in these schools may not conduct some activities. However, private schools provide teachers with more materials and equipment, and also encourage them to plan and conduct creative activities. These opportunities and experiences may influence professional attitudes of preschool teachers working in private schools positively.

The scores of teachers working in nursery classrooms were also higher than scores of those working in kindergartens. It may be result of differences between teachers' working hours in these institutions. Teachers in kindergartens usually work during all day, while their colleagues working in nursery classrooms work during half of the day. This means that nursery classroom teachers have the opportunity to spend other half of 
the day for their own works or planning the next day's educational activities, and preparing the necessary materials for these activities. It may positively affect the professional attitude of the teacher.

The scores of teachers of the age six were higher than and the teachers of age four or mixed age group. In preschool education period, the six-age groups are the age groups who have gained a lot of skills and are ready for primary school. Therefore, some matters such as classroom management and activity choice are easier in these groups. Also, this finding is supported by several studies in literature.

The scores of hourly paid teachers were also higher than salaried teachers. It may be resulted from that hourly paid teachers usually have recently graduated. Therefore, they wait for the appointment period, or prepare to enter the Public Personnel Selection Exam (KPSS). In other words, it may be a result of being a new idealist teacher in this profession.

Lastly, the scores of preschool teachers graduated from colleges (two-year) were higher than their colleagues' who graduated from school of education (four-year). This finding may be result of that graduates of colleges usually graduated from girl vocational high school. These high schools offer important opportunities for students in terms of planning and conducting activities, and prepare the students for teaching profession. When opportunities and importance of teaching practices during two-year college education are also considered, their attitudes toward teaching profession may be influenced positively.

In the light of the findings of the study, it is suggested that the factors that affect the attitudes of preschool teachers toward teaching profession should be examined through several studies and based on these factors, improvements which will affect their attitudes positively should be planned. It should be considered that the teachers' professional attitudes influence their job satisfactions, job burnout and job turnover so several improvement should be carried out to support teachers not only professionally but also in social and economic aspects.

For further studies, the examination of attitudes of preschool teachers toward teaching profession through a mixed-method study will be important to determine the causes of some results. The relationship between professional attitudes of preschool teachers and their classroom practices or the various skills of children in their classrooms can be examined. It can be examined how the professional attitudes of pre-service preschool teacher change over time. Lastly, the attitudes of in-service and pre-service preschool teachers toward teaching profession can be compared. 


\section{Kaynakça}

Ahmad, I., Said, H., Zeb, A., Sihatullah, Z., \& Ur Rehman, K. (2013). Effects of professional attitude of teachers on their teaching performance: Case of government secondary school teachers in Malakand Region, Khyber Pakhtunkhwa, Pakistan. Journal of Educational and Social Research, 3(1), 25-31.

Alkan, M. F. (2018). Investigation of pre-service teachers' attitudes towards teaching profession. SDU International Journal of Educational Studies, 5(1), 13-21.

Aslan, D., \& Köksal Akyol, A. (2006). Okul öncesi öğretmen adaylarının öğretmenlik mesleğine yönelik tutumları ve mesleki benlik saygılarının incelenmesi. Ç. $\ddot{U}$. Sosyal Bilimler Enstitüsü Dergisi, 15(2), 51-60.

Aybek, S. (2017). Her yönüyle tam gün eğitim. http://www.egitimajansi.com/sahinaybek/her-yonuyle-tam-gun-egitim-kose-yazisi-856y.html adresinden alınmıştır.

Aydın, R., \& Sağlam, G. (2012). Öğretmen adaylarının öğretmenlik mesleğine yönelik tutumlarının belirlenmesi (Mehmet Akif Ersoy Üniversitesi örneği). Türk Ĕ̌gitim Bilimleri Dergisi, 10(2), 257-294.

Ayık, A., \& Ataş, Ö. (2014). Öğretmen adaylarının öğretmenlik mesleğine yönelik tutumları ile öğretme motivasyonları arasındaki ilişki. Eğitim Bilimleri Araştırmaları Dergisi, 4(1), 25-48.

Bakay, M. E. (2014). Öğretmen devamsızlı̆̆ının incelenmesi: Menderes ilçesi örneği. Ege Ĕ̈itim Dergisi, 15(1), 233-250

Ball, D., \& Lampert, M. (1999). Multiples of evidence, time, and perspective: Revising the study of teaching and learning. In E. Lagemann \& L. Shulman (Ed.), Issues in education research: Problems and possibilities (pp. 371-398). New York: JosseyBass.

Bedel, E. F. (2008). Interactions among attitudes toward teaching and personality constructs in early childhood pre-service teachers. Eğitimde Kuram ve Uygulama, $4(1), 31-48$.

Bhargava, A., \& Pathy, M. K. (2014). Attitude of student teachers towards teaching profession. Turkish Online Journal of Distance Education, 15(3), 27-36.

Bulut, İ. (2009). Öğretmen adaylarının öğretmenlik mesleğine ilişkin tutumlarının değerlendirilmesi (Dicle ve Frrat Üniversitesi örneği). Dicle Üniversitesi Ziya Gökalp Eğitim Fakültesi Dergisi, 14, 13-24.

Büyüköztürk, Ş., Kılıç Çakmak, E., Akgün, Ö. E., Karadeniz, Ş., \& Demirel, F. (2014). Bilimsel araştırma yöntemleri. Ankara: Pegem Akademi.

Crano, W. D., \& Prislin, R. (2006). Attitudes and persuasion. Annual Review of Psychology, 57, 345-374.

Çınkır, Ş., \& Kurum, G. (2017). Atanmak ya da atanamamak: Ücretli öğretmenlerin yaşadıkları sorunlar. Eğitimde Nitel Araştırmalar Dergisi, 5(3), 9-35.

Demircioğlu, E., \& Özdemir, M. (2014). Fen ve edebiyat fakültesi öğrencilerinin öğretmenlik mesleğine yönelik tutumlarının çeşitli değişkenlere göre incelenmesi. Mersin Üniversitesi Eğitim Fakültesi Dergisi, 10(3), 110-122.

Divya, C. (2014). Attitude of teachers towards their profession and administration. The Criterion An International Journal in English, 5(4), 69-74. 
Doğan, S., Demir, S. B., \& Turan, N. (2013). Ücretli öğretmenlik uygulamasının değerlendirilmesi. Turkish Studies, 8(12), 371-390.

Durmuşçelebi, M., Yıldız, N., \& Sayg1, E. (2017). Öğretmen adaylarının öğretmenlik mesleğine ilişkin tutumlarının bazı değişkenler açısından incelenmesi. Uluslararası Toplum Araştırmaları Dergisi, 7(12), 8-32.

Eagly, A. H., \& Chaiken, S. (1993). The psychology of attitudes. Orlando, FL: Harcourt Brace Jovanovich College Publishers.

Ekici, F. Y. (2014). Öğretmen adaylarının öğretmenlik mesleğine yönelik tutumlarının çeşitli değişkenler açısından incelenmesi (İstanbul Sabahattin Zaim Üniversitesi örneği). Uluslararası Sosyal Araştırmalar Dergisi, 7(35), 658-665.

Elaldı, Ş., \& Yerliyurt, N. S. (2016). Preservice preschool teachers' self-efficacy beliefs and attitudes toward teaching profession. Educational Research and Reviews, 11(7), 345-357.

Engin, G., \& Çiçekli Koç, G. (2014). Öğretmen adaylarının öğretmenlik mesleğine yönelik tutumları (Ege Üniversitesi Eğitim Fakültesi örneği). Türkiye Sosyal Araştırmalar Dergisi, 182, 153-167.

Fazio, R. H., \& Olson, M. A. (2003). Attitudes: Foundations, functions, and consequences. In M. A. Hogg \& J. Cooper (Ed.), The SAGE handbook of social psychology (pp. 139-160). London: Sage.

Fraenkel, J. R., \& Wallen, N. E. (2006). How to design and evaluate research in education. New York, NY: McGraw-Hill, Inc.

Girgin, G., Özyılmaz Akamca, G., Ellez, A. M., \& Oğuz, E. (2010). Okul öncesi öğretmen adaylarının öğretmenlik mesleğine yönelik tutumları, mesleki benlik saygıları ve meslek yeterlik inançları. Buca Eğitim Fakültesi Dergisi, 28, 1-15.

İlgar, L. (2014). Özel okul ve devlet okulunda görev yapmış sınıf öğretmenlerinin sınıf yönetimindeki farklılıklara ilişkin görüşleri: Nitel bir çalışma. Hasan Ali Yücel Eğitim Fakültesi Dergisi, 11(22), 259-285.

Jambunathan, S., \& Caulfield, M. (2008). Developmentally appropriate practices in Asian Indian early childhood classrooms. Early Child Development and Care, 178(3), 251-258.

Jeon, L., Buettner, C. K., \& Hur, E. (2016). Preschool teachers' professional background, process quality, and job attitudes: A person-centered approach. Early Education and Development, 27(4), 551-571.

Jeon, L., \& Wells, M. B. (2018). An organizational-level analysis of early childhood teachers' job attitudes: Workplace satisfaction affects Early Head Start and Head Start Teacher turnover. Child Youth Care Forum, 47, 563-581.

Kağıtçıbaşı, Ç. (1985). İnsan ve insanlar. İstanbul: Beta.

Kalhotra, S. K. (2014). A study of teacher effectiveness in relation to attitude towards teaching profession. International Journal of Education and Psychological Research (IJEPR), 3(4), 9-13.

Karaduman, M. A. (2011). Pre-service teachers' attitudes towards the profession of early childhood education in terms of sex and gender role. (Yayımlanmamış yüksek lisans tezi), Sosyal Bilimler Enstitüsü, Orta Doğu Teknik Üniversitesi, Ankara. 
Karatekin, K., Merey, Z., \& Keçe, M. (2015). Sosyal bilgiler öğretmen adaylarının öğretmenlik mesleğine yönelik tutumları. YYÜ Eğitim Fakültesi Dergisi, 12, 70-96.

Khan, F., Nadeem, N. A., \& Basu, S. (2013). Professional attitude: A study of secondary teachers. Journal of Education Research and Behavioral Sciences, 2(8), 119-125.

Kızıltaş, E., Halmatov, M., \& Sarıçam, H. (2012). Okul öncesi öğretmenliği öğrencilerinin öğretmenlik mesleğine yönelik tutumları. Mehmet Akif Ersoy Üniversitesi Ĕ̆itim Fakültesi Dergisi, 23, 173-189.

Musa, A., \& Bichi, A. A. (2015). Assessment of prospective teachers attitudes towards teaching profession: The case of Northwest University, Kano-Nigeria. IOSR Journal of Research \& Method in Education, 5(3), 17-24.

NAEYC (2017). NAEYC Early Learning Standards and Accreditation Criteria\& Guidance for Assessment. https://www.naeyc.org/sites/default/files/globallyshared/downloads/PDFs/accreditation/early-

learning/Standards $\% 20$ and $\% 20$ Accreditation $\% 20$ Criteria $\% 20 \% 26 \% 20$ Guidance $\% 2$ 0for\%20Assessment_April\%202017_3.pdf adresinden alınmıştır.

OECD. (2009). Creating effective teaching and learning environments: First results from TALIS. http://www.oecd.org/edu/school/43023606.pdf adresinden alınmıştır.

Öğülmüş, K., Yıldırım, K., \& Aslan, G. (2013). Ücretli öğretmenlerin görevlerini yaparken karşılaştıkları sorunlar ve ücretli öğretmenlik uygulamasının okul yöneticilerince değerlendirilmesi. İlköğretim Online, 12(4), 1086-1099.

Özkubat, S. (2013). Okul öncesi kurumlarında eğitim ortamlarının düzenlenmesi ve donanım. Adnan Menderes Üniversitesi Ĕ̆itim Fakültesi Ĕ̆itim Bilimleri Dergisi, 4(2), 58-66.

Pickens, J. (2016). Attitudes and perceptions. In N. Borkowski (Ed.), Organizational behavior in health care (pp. 43-76). Burlington, MA: Jones \& Bartlett Learning.

Recepoğlu, E. (2013). Öğretmen adaylarının yaşam doyumları ile öğretmenlik mesleğine ilişkin tutumları arasındaki ilişkinin incelenmesi. Hacettepe Üniversitesi Ë̆itim Fakültesi Dergisi, Özel Sayı(1), 311-326.

Sak, R., Şahin-Sak, İ. T., Şahin, H. G., \& Şahin, B. K. (2018, Mart). Okul öncesi öğretmen adaylarının anasınıflarında karma yaş gruplarına ilişkin görüşleri. Bildiri, Uluslararası Bilim Ve Eğitim Kongresinde sözlü bildiri olarak sunulmuştur, Afyonkarahisar, Türkiye. (s. 461).

Sak, R., Şahin-Sak, İ. T., \& Yerlikaya, İ. (2015). Behavior management strategies: Beliefs and practices of male and female early childhood teachers. European Early Childhood Education Research Journal, 23(3), 328-39. http://dx.doi.org/10.1080/1350293X.2015.1043807.

Sak, R., Tantekin Erden, F., \& Morrison, G. S. (2016). Child-centred education: preschool teachers' beliefs and self-reported practices. Early Child Development and Care, 186(8), 1185-1202.

Semerci, N., \& Semerci, Ç. (2004). Türkiye'de öğretmenlik tutumları. Fırat Üniversitesi Sosyal Bilimler Dergisi, 14(1), 137-146.

Soibamcha, E. (2016). Attitude of teachers towards teaching profession. Journal of Research in Humanities and Social Science, 4(6), 103-105. 
Şahin-Sak, İ. T. (2015). Okul öncesi öğretmen adaylarının sınıf yönetimi ile ilgili özyeterlik inançları. Sakarya Üniversitesi Eğitim Fakültesi Dergisi, 29, 101-120.

Şahin-Sak, İ. T., Tantekin-Erden, F., \& Pollard-Durodola, S. (2018). Turkish preschool teachers' beliefs and practices related to two dimensions of developmentally appropriate classroom management. Education 3-13, 46(1), 102-116. http://dx.doi.org/10.1080/03004279.2016.1194447

Tanel, R., Kaya Şengören, S., \& Tanel, Z. (2007). Fizik öğretmen adaylarının öğretmenlik mesleğine ilişkin tutumlarının farklı değişkenler açısından incelenmesi. Pamukkale Üniversitesi Ĕ̈itim Fakültesi Dergisi, 22, 1-9.

Tekerek, M., \& Polat, S. (2011). Öğretmen adaylarının öğretmenlik mesleğine ilişkin tutumlart. Bildiri, 5. International Computer \& Instructional Technologies Symposium'da sözlü bildiri olarak sunulmuştur, Elazığg, Türkiye.

Trivedi, T. (2011). Assessing secondary school teachers' attitude towards teaching profession. E-journal of All India Association for Educational Research (EJAIAER), 23(1-2), 91-110.

Üstün, E., Erkan, S., \& Akman, B. (2004). Türkiye'de okul öncesi öğretmenliği öğrencilerinin öğretmenlik mesleğine yönelik tutumlarının incelenmesi. Kırgızistan-Türkiye Manas Üniversitesi Sosyal Bilimler Dergisi, 10, 129-136.

Üstüner, M. (2006). Öğretmenlik Mesleğine Yönelik Tutum Ölçeğinin geçerlik ve güvenirlik çalışması. Kuram ve Uygulamada Eğitim Yönetimi, 45, 109-127.

Vujičić, L., \& Čamber Tambolaš, A. (2017). Professional development of preschool teachers and changing the culture of the institution of early education. Early Child Development and Care, 187(10), 1583-1595. http://dx.doi.org/ 10.1080/03004430.2017.1317763

Wells, M. B. (2017). Is all support equal?: Head Start preschool teachers' psychological job attitudes. Teaching and Teacher Education, 63, 103-115.

Yayla, A., Sak, R., Şahin-Sak, İ. T., \& Taşkın, N. (2018). Comparing the job satisfaction of hourly paid and salaried preschool teachers in Turkey, Education 313, 46(7), 814-824. http://dx.doi.org/10.1080/03004279.2017.1365919.

This is an Open Access article distributed under the terms of the Creative CommonsAttribution- 